\title{
Multicriteria Decision Making using Analytic Hierarchy Process for Child Protection from Malicious Content on the Internet
}

\author{
Fargana J. Abdullayeva \\ Institute of Information Technology, Azerbaijan National Academy of Sciences, Baku, Azerbaijan \\ E-mail: a_farqana@mail.ru \\ Sabira S. Ojagverdiyeva \\ Institute of Information Technology, Azerbaijan National Academy of Sciences, Baku, Azerbaijan \\ E-mail: allahverdiyevasabira@gmail.com
}

Received: 02 March 2021; Accepted: 13 April 2021; Published: 08 June 2021

\begin{abstract}
Modern children are active Internet users. However, in the context of information abundance, they have little knowledge of which information is useful and which is harmful. To make the Internet a safe place for children, various methods are used at the international and national levels, as well as by experts, and the ways to protect children from harmful information are sought. The article proposes an approach using a multi-criteria decision-making process to prevent children from encountering harmful content on the Internet and to make the Internet more secure environment for children. The article highlights the age characteristics of children as criteria. Harmless information, Training information, Entertainment information, News, and Harmful information are considered as alternatives. Here, a decision is made by comparing the alternatives according to the given criteria. According to the trials, harmful information is rated in the last position.

There is no child protection issue on the Internet using the AHP method. This research is important to protect children from harmful information in the virtual space. In the protection of minors Internet users is a reliable approach for educational institutions, parents and other subjects related to child safety.
\end{abstract}

Index Terms: Kids safety, AHP, age groups, harmful contents, child online protection.

\section{Introduction}

Along with the positive aspects of the expansion of the Internet and the emergence of new media platforms, it has also caused certain problems. As a result, this new form of communication has made children and adolescents to encounter harmful content on the Internet and to have security problems online.

A child is a person under 18 [1]. Obviously, these modern children grow up in a digital environment, they are active Internet users, and over time, the use of the Internet by children begins at an early age. The use of smartphones and tablets brings children closer to the world of information, as well as to malicious information and cyber threats against them. This affects their behavior, intellectual level, emotional state, in short, their psychology.

Today, a large number of software is used to address the issue of safe use of the Internet by children and adolescents. These programs provide information on cyber threats, ways to protect against threats, and even provide psychological support to victims of cyber attacks [2].

In the context of big data, it is doubtful that the information that children and adolescents get from the Internet is always positive [3,4]. Even in child-friendly applications such as YouTube Kids, which is considered a safe platform, we can come across the videos with inappropriate content [5].

The information that affects the psychology and health of children, as well as the content that encourages that information, are considered to be harmful. The Council of Europe's report "Protection of Children from Harmful Content" classifies the types of harmful data intended for children as follows [6]: propagating information (information harmful to health, propagating alcohol, drugs, gambling, begging, etc.); non-censored expressions (swearing, slang, insulting expressions, etc.); pornographic information (sexual intercourse in the form of photos and images); content promoting violence and fear (providing pictures of the consequences of violence, cruelty, violence, disaster and accidents); sharing personal data (identity, place of study, etc.) of the child.

The problem of protection against harmful information is one of the most pressing security issues in almost all countries. Exposure to harmful content varies by type of harmful information, as well as by countries. According to a study [7], $48 \%$ of children in Poland experience more hatred messages per month, while $19 \%$ of children encounter the 
content that contains only physical harm or suicide. In Germany, exposure to harmful content affects $2-6 \%$ of children per month, while in Slovakia this figure varies from $2 \%$ to $8 \%$.

In order to protect children and adolescents from such influences, the presence of teachers, parents, guardians, national legal regulation is not enough, and new technological methods, techniques, parental control and content filtering mechanisms, decision-making systems, etc. are required.

The presence of teachers, parents, guardians and national legislation are not enough to protect children and adolescents from such influences. However, it is important to have more reliable software, methods, algorithms, prediction systems and mechanisms that include many features (malware detection, intruder identification, psychodiagnostic analysis features, malicious content filtering programs, parental control systems, etc.).

Suitable for minors when searching for information and confronting web pages that offer harmless content is very important in terms of information security. The article presents a series of multi-criteria decision-making tasks aimed at obtaining age-appropriate content in various types of information (useful, useless, vulgar, terrorist, gambling addiction, etc.) in the Internet environment. This approach aims to make the Internet a safer environment for children. It aims to keep children safe online while parents, teachers and other officials cannot monitor their children's online activities.

The sections of the paper are organized as follows: Section II provides an overview of related work; Section III provides information about the Multi-criteria decision-making and AHP (Analytical Hierarchy Process). Section IV describes the model of the problem, and Section V solves it using AHP. Section VI presents Future Research Directions. Finally, Section VII contains the result.

\section{Related Work}

Various methods and technologies are used to protect young users from harmful information in the Internet environment. For this purpose, children data are analyzed and monitored to determine which websites they visit the most, and certain predictive decisions are made. These approaches are intended to prevent any illegal, inappropriate, suspicious or harmful information. To prevent children from encountering inappropriate information when they surf the Internet, [8] offers a "Child Safe Search Classification Model" that filters the website's content. It proposes a feature selection method together with the Modified Entropy term weighting scheme, PCA and Neural Network Classifier. It performs $63 \%$ accuracy.

The lack of a safe Internet environment for children and adolescents suggests the design and implementation of an individual Internet access for children, known as PIAK [9], which takes into account the presence of malicious web pages. PIAK development process for convenience and safety of children when using the Internet in Malaysia is designed to meet the needs of local children in Sarawak.

Some studies also show how to restrict children's access to the Internet using biometric data. Based on biometric characteristics [10], young users are differentiated from the elder users by analyzing the writing style on the keyboard and touch screen. It aims to automatically limit children's abuse of Internet threats and talents, both on the touch screen and in the Android environment. Another study [11] provides Internet security by successfully determining whether a user is under 15 or not to predict the Keystroke Dynamics.

Since the Internet search engines are designed particularly for adults, children's desire for information acquisition causes a number of concerns. Given the need for search engines to create a more relevant and reliable virtual environment for children's audiences, [12] offers the concept of Information Retrieval with Document Filtering, which filters pornographic information. It categorizes age-appropriate and accessible information for children as "safe" group, and other information as "dangerous" group. The document filter uses the Naive Bayes algorithm to categorize documents.

Protecting children and adolescents from age-inappropriate information is important for their safety. Due to the fact that pornographic information (images, audio, video, pornographic texts) is very vulnerable information for children, [13] uses data sanitization method. Thus, it proposes the approach the first block of which is an auto-encoder deep neural network, and the second block is a logistic regression classifier. According to the results of the experiment, it can almost classify and recognize sensitive data with low accuracy. As a result, sensitive content is cleansed and presented to young user. [14] also proposes an approach based on Deep Generative Adversarial Networks to perform data sanitization (cleansing) in order to delete malicious image content and to manage children's access to malicious information on the Internet.

Detection of harmful web pages is mostly based on blacklists. The proposed content filtering system offers a hybrid approach using a blacklisted URL database and the Naïve Bayes algorithm. By blocking a link to a malicious website, it stores only positive results in the list and presents them to the user. However, this content is intended to be accessible only to children aged 5-12 [15]. Another study also classifies URLs based on the web pages dynamics [16]. It aims at determining if the content of a website is specific to a child audience. Various experiments on open data perform $82.04 \%$ accuracy.

Users comment on children's videos on Youtube and other channels. These comments often include inappropriate, illegal content, hatred expression, toxic language, and so on. [17] bases on the fact that children and adolescents are exposed to more risks and dangers when using more social networks (YouTube, Facebook, Twitter, etc.), taking into 
account the presence of malicious Urls in these comments. Proposed architecture offers an advanced family counseling package that protects user-centric privacy to protect minors [17].

Another study uses user data and sorts out the video and other users' information related to the same video, and then sorts out the video content. By filtering data using Deep Neural Networks, inappropriate content targeting young children on YouTube channel can be identified with $84.3 \%$ accuracy [18]. Another study proposes an approach to advanced one-time content filter (slicing and imaging, sound and transcription analysis) using automated video and audio analysis as an additional layer for children's safety, given the fact that inappropriate content has metadata properties that can pass through the filtering mechanism on YouTube Kids [19].

Given that the propagation of alcohol and drugs is prohibited for children, some studies automatically detect and analyze the content of text, images and videos [20].

Revision of some research shows that despite the fact that there is enough research on the protection of children from harmful information, threats, cybercrimes and etc. in global networks, there is a need to create software that takes into account human interactions in social networks, forums, and other virtual environments. The availability of these methods is very important in solving the problem of children's safe use of the Internet.

\section{Multi-criteria Decision-Making}

Multi-criteria decision making is a field of decision theory. It combines the most widely used methods. It is based on modeling and analysis of decision period for criteria. It includes methods for the evaluation of multiple decision criteria and selection of alternatives, grouping or listing of alternatives [21,22,23].

Multi-criteria decision-making tasks are more common in daily life. This theory is a typical starting point for practical and theoretical analysis. These methods guide the decision-maker in the problem-solving process, which is based on choosing the best alternative out of many pre-determined alternatives, taking into account more than one criterion in the decision-making process [24]. Each of the MCDM methods used in the decision-making process on the selection out of a set of alternative solutions uses numerical methods. The following three steps should be followed in the application of the decision-making method, which includes quantitative analysis of alternatives:

- Determination of alternatives and criteria,

- Determination of relative importance weight of the criteria,

- Evaluation and determination of each alternative for all criteria.

Many AHP has been recently used to solve multi-criteria decision-making (MCDM) problems. The AHP method is a relatively simple and practical tool, that converts the decision-maker's thinking period into quantitative and qualitative data, and then analyzes multi-criteria data using simple mathematics [25].

\subsection{AHP (Analytical Hierarchy Process)}

The process of analytical hierarchy is a task of multi-criteria decision-making [26]. The analytical hierarchy process is a method of ranking the alternatives and selecting the best alternative according to a number of given criteria. AHP creates a numerical score to rank each alternative. The process of analytical hierarchy was proposed by Thomas Saaty in 1970 [27].

The process of analytical hierarchy is applied to many areas, such as site selection for organization, purchase of a new car, choice of career, and prediction of political victory in elections. Although this method is applied in many areas [28], AHP has not been used to protect children on the Internet. AHP allows making complex decisions. That is, it is based on a comparison of the elements involved in decision-making which are difficult to [29] calculate. The AHP algorithm includes the following steps:

Step 1. Determining a decision-making task;

Step 2. Developing a conceptual approach;

Step 3. Establishing a decision-making hierarchy;

Step 4. Collecting data from experts;

Step 5. Performing pair comparison;

Step 6. Estimating relative weights of elements;

Step 7. Calculating the degree of conformity;

Step 8. Calculating the average relative weights.

\section{Model}

The issue is how to protect children from harmful information that is not age-appropriate in the online environment. Assume that children are required to access information from the Internet and have options such as Harmless Information, Training Information, Entertaining Information, News, and Harmful Information. The selection criteria for 
these alternatives include the children under 6 age, children over 6 age, children over 12 age, children over 16 age, and users over 18 age. Here, decision is made by comparing the alternatives for the given criteria.

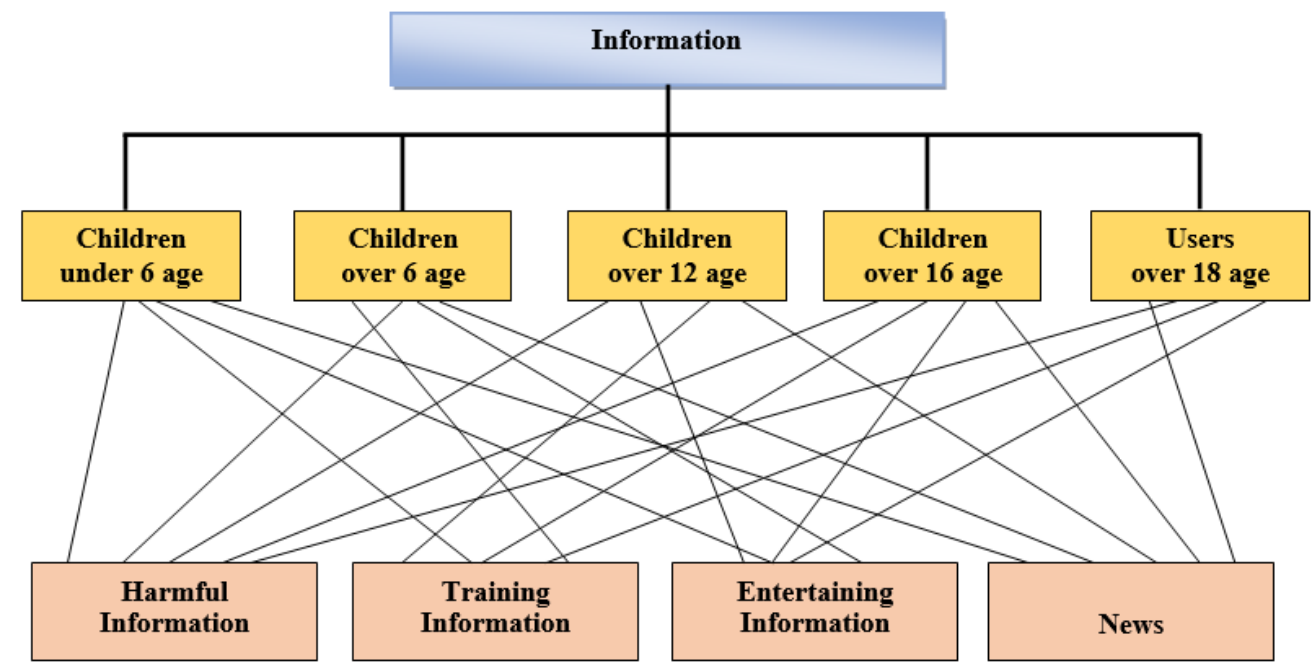

Fig.1. Decomposition of the decision-making problem into a hierarchy of criteria and alternatives

Fig.1 is described as follows:

Layer 1 - purpose of analysis;

Layer 2 - set of criteria;

Layer 3 - alternatives to be selected.

\section{Problem Solution through AHP}

Creating comparison metrics. A ranking scale of nine divisions is used to perform a pairwise comparison among five given criteria. The ranking scale determines the relative importance of the elements to each other, and the values of these elements can vary within 1-9. The comparison matrix according to the ranking scale of criteria is developed as in Table 1.

Table 1. Comparison matrix according to the ranking scale of criteria

\begin{tabular}{|c|c|c|c|c|c|}
\hline Age & Children under 6 age & Children over 6 age & Children over 12 age & Children over 12 age & Users over 18 age \\
\hline Children under 6 age & $\mathbf{1}$ & 5 & 3 & 2 & 2 \\
\hline Children over 6 age & 0.2 & $\mathbf{1}$ & 2 & 4 & 5 \\
\hline Children over 12 age & 0.3 & 0.5 & $\mathbf{1}$ & 5 & 4 \\
\hline Children over 16 age & 0.5 & 0.3 & 0.2 & $\mathbf{1}$ & 3 \\
\hline Users over 18 age & 0.5 & 0.4 & 0.25 & 0.3 & $\mathbf{1}$ \\
\hline sum & 2.5 & 7.2 & 6.45 & 12.3 & 15 \\
\hline
\end{tabular}

Table 1 presents the criteria in column 1 and row 1, respectively. The cells where these row and column elements intersect shows the values according to the degree of preference. The diagonal elements of the table include values of 1. Because a pairwise comparison of the same criterion will equal to 1. Since younger children are preferred as they are more important, and therefore the highest values are given in the upper right cells of the diagonal, and the lower left cells of the diagonal are given relatively lower values.

The second step of the AHP involves the normalization of the preference rates matrix provided in Table 1 . To perform the normalization, the value of each cell in Table 1 is calculated as the ratio of the sum of the corresponding columns. The normalization matrix of Table 1 calculated in this way is presented in Table 2 . Here the calculation must be performed in such a way that the sum of the elements of the corresponding column will equal to only 1 . The average value of the elements of the corresponding row is calculated using the Average function of MS Excel. 
Table 2. Normalized comparison matrix according to the ranking scale of criteria

\begin{tabular}{|c|c|c|c|c|c|c|}
\hline Criteria & $\begin{array}{c}\text { Children } \\
\text { under 6 age }\end{array}$ & $\begin{array}{c}\text { Children } \\
\text { over 6 age }\end{array}$ & $\begin{array}{c}\text { Children over } \\
\text { 12 age }\end{array}$ & $\begin{array}{c}\text { Children over } \\
16 \text { age }\end{array}$ & $\begin{array}{c}\text { Users over } \\
18 \text { age }\end{array}$ & Average \\
\hline Children under 6 age & 0.394736842 & 0.694444444 & 0.465116279 & 0.162162162 & 0.133333333 & 0.369958612 \\
\hline Children over 6 age & 0.078947368 & 0.138888889 & 0.310077519 & 0.324324324 & 0.3333333333 & 0.237114287 \\
\hline Children over 12 age & 0.131578947 & 0.069444444 & 0.15503876 & 0.405405405 & 0.266666667 & 0.205626845 \\
\hline Children over 16 age & 0.197368421 & 0.041666667 & 0.031007752 & 0.081081081 & 0.2 & 0.110224784 \\
\hline Users over 18 age & 0.197368421 & 0.055555556 & 0.03875969 & 0.027027027 & 0.066666667 & 0.077075472 \\
\hline SUM & 1 & 1 & 1 & 1 & 1 & 1 \\
\hline
\end{tabular}

Thus, Table 2 shows that the importance of children under 6 age in decision-making accounts for $36 \%$, the importance of children over 6 age - 23\%, the importance of children over 12 age - 20\%, the importance of children over 16 age- $11 \%$, and the importance of users over 18 age $-7 \%$.

The consistency ratio must be calculated to verify that the consistency relation is satisfied in the pairwise comparison. Consistency ratio should not exceed $10 \%$. Otherwise, the operations on previous stage will be repeated. If the number of criteria is high, a consistency ratio greater than 10 is considered normal.

The following formula is used to calculate the consistency index:

$$
C I=\frac{\lambda_{\max }-n}{n-1}
$$

where $\lambda_{\max }$ denotes principal Eigenvalue, $n$ - the measure of the matrix (in our case, it is 5). To calculate the consistency ratio, first the ratio $\lambda_{\max }$ has to be calculated. For this, the figure in front of the criterion 1 in Table 1 is multiplied by the average value of that criterion in Table 2. Appropriate calculations are performed for all values of the comparison criteria in Table 1 and the results are presented in Table 3. Here, the corresponding column elements of the comparison matrix (Table 1) are multiplied by the average value of the corresponding row of the normalization matrix (Table 2).

Table 3. Calculation of Lambda ratio

\begin{tabular}{|c|c|c|c|c|c|c|}
\hline $\begin{array}{c}\text { Children } \\
\text { under 6 age }\end{array}$ & $\begin{array}{c}\text { Children } \\
\text { over 6 age }\end{array}$ & $\begin{array}{c}\text { Children } \\
\text { over 12 age }\end{array}$ & $\begin{array}{c}\text { Children } \\
\text { over 16 age }\end{array}$ & $\begin{array}{c}\text { Users } \\
\text { over 18 age }\end{array}$ & $\begin{array}{c}\text { Consistency } \\
\text { vector }\end{array}$ \\
\hline 0.369958612 & 1.185571434 & 0.616880534 & 0.220449568 & 0.154150944 & 2.547011093 & 6.884583867 \\
\hline 0.073991722 & 0.237114287 & 0.411253689 & 0.440899137 & 0.38537736 & 1.548636196 & 6.531180453 \\
\hline 0.123319537 & 0.118557143 & 0.205626845 & 0.551123921 & 0.308301888 & 1.306929334 & 6.355830321 \\
\hline 0.184979306 & 0.071134286 & 0.041125369 & 0.110224784 & 0.231226416 & 0.638690161 & 5.794433315 \\
\hline 0.184979306 & 0.094845715 & 0.051406711 & 0.036741595 & 0.077075472 & 0.445048799 & 5.774194916 \\
\hline Lambda & & & & & & \\
\hline
\end{tabular}

In Table 3, the values of column Sum are calculated as the sum of the values of each row using the Sum function of MS Excel. In the next step, the consistency vector has to be calculated. To find the consistency vector, the corresponding element of column Sum in Table 3 is divided by the corresponding value of the average value of the normalization matrix in Table 2 . The average value of the values of the consistency vector column provides the Lambda ratio. The Average function of MS Excel is used to calculate the Lambda. Thus, once the values of Lambda ratio and the variable $n$ are known, the consistency index is calculated with formula (1) and presented in Table 4.

Table 4. Calculation of CI and CR ratios

\begin{tabular}{|c|c|}
\hline Number of criteria (n) & 5 \\
\hline (Consistency Index, CI) & 0.317011144 \\
\hline (Consistency Ratio, CR) & $28 \%$ \\
\hline
\end{tabular}

The following formula is used to calculate the Consistency Ratio (CR).

$$
C R=C I / R I
$$

Here, CI is the consistency index, and RI is the Random Consistency Index (RI) suggested by Saaty and is described by the values in the table below. 


\begin{tabular}{|c|c|c|c|c|c|c|c|c|c|c|}
\hline $\mathrm{n}$ & 1 & 2 & 3 & 4 & 5 & 6 & 7 & 8 & 9 & 10 \\
\hline $\mathrm{RI}$ & 0 & 0 & 0,525 & 0,882 & 1,115 & 1,252 & 1,341 & 1,404 & 1.452 & 1,484 \\
\hline
\end{tabular}

In our case, since the number of criteria $(n)$ is 5 , the value of RI is taken from the table above, RI $=1,115$. Thus, according to the formula (2), the consistency ratio is obtained by dividing the consistency index by the RI, if $n=5$. That is, $\mathrm{CR}=0.317011144 / 1,115=0.284315=28 \%$ is obtained (Table 4 ).

After the abovementioned calculations, a pairwise comparison matrix of alternatives for each criterion and a normalized matrix of this comparison matrix have to be developed to construct the alternative selection matrix. Applying the calculations performed in step 1 above, the pairwise comparison matrix of alternatives for children under 6 age can be constructed as in Table 5 .

Table 5. Pairwise comparison matrix of alternatives for children under 6 age

\begin{tabular}{|c|c|c|c|c|c|}
\hline Alternatives & $\begin{array}{c}\text { Harmless } \\
\text { information }\end{array}$ & Training information & $\begin{array}{c}\text { Entertaining } \\
\text { information }\end{array}$ & News & 5 \\
\hline Harmless information & $\mathbf{1}$ & 7 & $\mathbf{1}$ & 0.333333333 & 4 \\
\hline Training information & 0.142857143 & 3 & $\mathbf{1}$ & 5 \\
\hline Entertaining information & 0.2 & 0.3 & 0.2 & $\mathbf{1}$ \\
\hline News & 0.5 & 0.125 & 0.142857143 & 0.2 & 0.25 \\
\hline Harmful information & 1.967857143 & 11.44285714 & 6.733333333 & 12.25 \\
\hline Sum & & & $\mathbf{1}$ \\
\hline
\end{tabular}

The normalized form of Table 5 is presented in Table 6 below.

Table 6. Normalized matrix of pairwise comparison of alternatives matrix for children under 6 age

\begin{tabular}{|c|c|c|c|c|c|c|}
\hline Alternatives & $\begin{array}{c}\text { Harmless } \\
\text { information }\end{array}$ & $\begin{array}{c}\text { Training } \\
\text { information }\end{array}$ & $\begin{array}{l}\text { Entertaining } \\
\text { information }\end{array}$ & News & $\begin{array}{c}\text { Harmful } \\
\text { information }\end{array}$ & Average \\
\hline Harmless information & 0.508166969 & 0.611735331 & 0.742574257 & 0.163265306 & 0.32 & 0.469148373 \\
\hline Training information & 0.072595281 & 0.087390762 & 0.04950495 & 0.326530612 & 0.28 & 0.163204321 \\
\hline Entertaining information & 0.101633394 & 0.262172285 & 0.148514851 & 0.408163265 & 0.2 & 0.224096759 \\
\hline News & 0.254083485 & 0.026217228 & 0.02970297 & 0.081632653 & 0.16 & 0.110327267 \\
\hline Harmful information & 0.063520871 & 0.012484395 & 0.02970297 & 0.020408163 & 0.04 & 0.03322328 \\
\hline Sum & 1 & 1 & 1 & 1 & 1 & 1 \\
\hline
\end{tabular}

Table 7. Pairwise comparison matrix of alternatives for children over 6 age

\begin{tabular}{|c|c|c|c|c|c|}
\hline Alternatives & Harmless information & Training information & Entertaining information & News & Harmful information \\
\hline Harmless information & 1 & 4 & 7 & 3 & 8 \\
\hline Training information & 0.25 & 1 & 0.142857143 & 5 & 7 \\
\hline Entertaining information & 0.142857143 & 3 & 1 & 5 & 5 \\
\hline News & 0.333333333 & 0.3 & 0.2 & 1 & 4 \\
\hline Harmful information & 0.125 & 0.142857143 & 0.2 & 0.25 & 1 \\
\hline Sum & 1.851190476 & 8.442857143 & 8.542857143 & 14.25 & 25 \\
\hline
\end{tabular}

The normalized form of Table 7 is presented in Table 8 below.

Table 8. Normalized matrix of pairwise comparison of alternatives matrix for children over 6 age

\begin{tabular}{|c|c|c|c|c|c|c|}
\hline Alternatives & $\begin{array}{c}\text { Harmless } \\
\text { information }\end{array}$ & $\begin{array}{c}\text { Training } \\
\text { information }\end{array}$ & $\begin{array}{c}\text { Entertaining } \\
\text { information }\end{array}$ & News & Harmful information & Average \\
\hline Harmless information & 0.540192926 & 0.473773266 & 0.819397993 & 0.210526316 & 0.32 \\
\hline Training information & 0.135048232 & 0.118443316 & 0.016722408 & 0.350877193 & 0.4727781 \\
\hline Entertaining information & 0.077170418 & 0.355329949 & 0.117056856 & 0.350877193 & 0.28 & 0.18021823 \\
\hline News & 0.180064309 & 0.035532995 & 0.023411371 & 0.070175439 & 0.220086883 \\
\hline Harmful information & 0.067524116 & 0.016920474 & 0.023411371 & 0.01754386 & 0.16 & 0.093836823 \\
\hline Sum & 1 & 1 & 1 & 1 & 0.033079964 \\
\hline
\end{tabular}


Table 9. Pairwise comparison matrix of alternatives for children over 12 age

\begin{tabular}{|c|c|c|c|c|c|}
\hline Alternatives & Harmless information & Training information & Entertaining information & News & Harmful information \\
\hline Harmless information & $\mathbf{1}$ & 2 & 3 & 1 & 8 \\
\hline Training information & 0.5 & $\mathbf{1}$ & 2 & 5 & 7 \\
\hline Entertaining information & 0.142857143 & 0.5 & $\mathbf{1}$ & 4 & 5 \\
\hline News & 0.333333333 & 0.2 & 0.25 & $\mathbf{1}$ & 4 \\
\hline Harmful information & 0.125 & 0.142857143 & 0.2 & 0.25 & $\mathbf{1}$ \\
\hline Sum & 2.101190476 & 3.842857143 & 6.45 & 11.25 & 25 \\
\hline
\end{tabular}

The normalized form of Table 9 is presented in Table 10 below.

Table 10. Normalized matrix of pairwise comparison of alternatives matrix for children over 12 age

\begin{tabular}{|c|c|c|c|c|c|c|}
\hline Alternatives & Harmless information & Training information & Entertaining information & News & $\begin{array}{c}\text { Harmful } \\
\text { information }\end{array}$ & Average \\
\hline Harmless information & 0.47592068 & 0.520446097 & 0.465116279 & 0.0888888889 & 0.32 & 0.374074389 \\
\hline Training information & 0.23796034 & 0.260223048 & 0.310077519 & 0.444444444 & 0.28 & 0.30654107 \\
\hline Entertaining information & 0.067988669 & 0.130111524 & 0.15503876 & 0.3555555556 & 0.2 & 0.181738902 \\
\hline News & 0.158640227 & 0.05204461 & 0.03875969 & 0.0888888889 & 0.16 & 0.099666683 \\
\hline Harmful information & 0.059490085 & 0.037174721 & 0.031007752 & 0.022222222 & 0.04 & 0.037978956 \\
\hline Sum & 1 & 1 & 1 & 1 & 1 & 1 \\
\hline
\end{tabular}

Table 11. Pairwise comparison matrix of alternatives for children over 16 age

\begin{tabular}{|c|c|c|c|c|c|}
\hline Alternatives & Harmless information & Training information & Entertaining information & News & Harmful information \\
\hline Harmless information & $\mathbf{1}$ & 0.25 & 0.142857143 & 0.333333333 & 8 \\
\hline Training information & 4 & $\mathbf{1}$ & 2 & 5 & 7 \\
\hline Entertaining information & 7 & 3 & $\mathbf{1}$ & 5 & 5 \\
\hline News & 3 & 0.3 & 0.2 & $\mathbf{1}$ & 4 \\
\hline Harmful information & 0.125 & 0.142857143 & 0.2 & 0.25 & $\mathbf{1}$ \\
\hline Sum & 15.125 & 4.692857143 & 3.542857143 & 11.58333333 & 25 \\
\hline
\end{tabular}

The normalized form of Table 11 is presented in Table 12 below.

Table 12. Normalized matrix of pairwise comparison of alternatives matrix for children over 16 age

\begin{tabular}{|c|c|c|c|c|c|c|}
\hline Alternatives & $\begin{array}{c}\text { Harmless } \\
\text { information }\end{array}$ & $\begin{array}{c}\text { Training } \\
\text { information }\end{array}$ & $\begin{array}{c}\text { Entertaining } \\
\text { information }\end{array}$ & News & $\begin{array}{c}\text { Harmful } \\
\text { information }\end{array}$ & Average \\
\hline Harmless information & 0.066115702 & 0.053272451 & 0.040322581 & 0.028776978 & 0.32 & 0.101697542 \\
\hline Training information & 0.26446281 & 0.213089802 & 0.564516129 & 0.431654676 & 0.28 & 0.350744683 \\
\hline Entertaining information & 0.462809917 & 0.639269406 & 0.282258065 & 0.431654676 & 0.2 & 0.403198413 \\
\hline News & 0.198347107 & 0.063926941 & 0.056451613 & 0.086330935 & 0.16 & 0.113011319 \\
\hline Harmful information & 0.008264463 & 0.0304414 & 0.056451613 & 0.021582734 & 0.04 & 0.031348042 \\
\hline Sum & 0.991735537 & 1 & 1 & 1 & 1 & 1 \\
\hline
\end{tabular}

Table 13. Pairwise comparison matrix of alternatives for children over 18 age

\begin{tabular}{|c|c|c|c|c|c|}
\hline Alternatives & Harmless information & Training information & Entertaining information & News & $\begin{array}{c}\text { Harmful } \\
\text { information }\end{array}$ \\
\hline Harmless information & $\mathbf{1}$ & 0.25 & 0.166666667 & 0.5 & 4 \\
\hline Training information & 5 & $\mathbf{1}$ & 0.2 & 5 & 3 \\
\hline Entertaining information & 3 & 3 & $\mathbf{1}$ & 5 & 2 \\
\hline News & 2 & 0.2 & 0.2 & 1 & 2 \\
\hline Harmful information & 0.25 & 0.333333333 & 0.5 & 0.5 & $\mathbf{1}$ \\
\hline Sum & 11.25 & 4.783333333 & 2.066666667 & 12 & 12 \\
\hline
\end{tabular}

The normalized form of Table 13 is presented in Table 14 below. 
Table 14. Normalized matrix of pairwise comparison of alternatives matrix for children over 18 age

\begin{tabular}{|c|c|c|c|c|c|c|}
\hline Alternatives & $\begin{array}{c}\text { Harmless } \\
\text { information }\end{array}$ & $\begin{array}{c}\text { Training } \\
\text { information }\end{array}$ & $\begin{array}{l}\text { Entertaining } \\
\text { information }\end{array}$ & News & $\begin{array}{c}\text { Harmful } \\
\text { information }\end{array}$ & Average \\
\hline Harmless information & 0.088888889 & 0.052264808 & 0.080645161 & 0.041666667 & 0.333333333 & 0.119359772 \\
\hline Training information & 0.444444444 & 0.209059233 & 0.096774194 & 0.416666667 & 0.25 & 0.283388908 \\
\hline Entertaining information & 0.266666667 & 0.6271777 & 0.483870968 & 0.416666667 & 0.166666667 & 0.392209734 \\
\hline News & 0.177777778 & 0.041811847 & 0.096774194 & 0.083333333 & 0.166666667 & 0.113272764 \\
\hline Harmful information & 0.022222222 & 0.069686411 & 0.241935484 & 0.041666667 & 0.083333333 & 0.091768823 \\
\hline Sum & 1 & 1 & 1 & 1 & 1 & 1 \\
\hline
\end{tabular}

To build an alternative matrix, the values of the column of average value of the corresponding criteria in Tables 6 , $8,10,12,14$ above are presented in Table 15 respectively. Here, the values of the Weightage parameter are the Average values of the normalized comparison matrix according to the ranking scale of the criteria presented in Table 2 . The Matrix Multiplication (MMULT) function of MS Excel is used to rank the alternatives, and the values obtained are presented in the Score column in Table 15.

Table 15. Alternative selection matrix

\begin{tabular}{|c|c|c|c|c|c|c|c|}
\hline Alternatives & $\begin{array}{c}\text { Children } \\
\text { under 6 }\end{array}$ & $\begin{array}{c}\text { Children } \\
\text { over 6 }\end{array}$ & $\begin{array}{c}\text { Children } \\
\text { over 12 }\end{array}$ & $\begin{array}{c}\text { Children } \\
\text { over 12 }\end{array}$ & $\begin{array}{c}\text { Users } \\
\text { over 18 }\end{array}$ & Weightage & Score \\
\hline Harmless information & 0.469148373 & 0.4727781 & 0.374074389 & 0.101697542 & 0.119359772 & 0.369958612 & 0.382997 \\
\hline Training information & 0.163204321 & 0.18021823 & 0.30654107 & 0.350744683 & 0.283388908 & 0.237114287 & 0.226647 \\
\hline Entertaining information & 0.224096759 & 0.220086883 & 0.181738902 & 0.403198413 & 0.392209734 & 0.205626845 & 0.247135 \\
\hline News & 0.110327267 & 0.093836823 & 0.099666683 & 0.113011319 & 0.113272764 & 0.110224784 & 0.104748 \\
\hline Harmful information & 0.03322328 & 0.033079964 & 0.037978956 & 0.031348042 & 0.091768823 & 0.077075472 & 0.038473 \\
\hline
\end{tabular}

The values in column Score in Table 15 are included in Table 16 according to the corresponding alternatives.

Table 16. Alternatives Ranking based on the Matrix Multiplication (MMULT) function

\begin{tabular}{|c|l|}
\hline Harmless information & $\mathbf{0 . 3 8 2 9 9 7}$ \\
\hline Training information & 0.226647 \\
\hline Entertaining information & 0.247135 \\
\hline News & 0.104748 \\
\hline Harmful information & 0.038473 \\
\hline
\end{tabular}

As Table 16 shows, the preferred type of information to be presented to children's audience is harmless information and accounts for 0.382997. Harmful information is rated in the last position and accounts for 0.038473. The experiments are performed on MS Excel software.

\section{Future Research Directions}

At a time when various types of information are being collected on the Internet in an abundance of information, children and adolescents are exposed to harmful and inappropriate content in the Internet environment. In our future research, we will continue our research, taking into account not only the age factor, but also other parameters to protect children from Internet threats. This includes the development of a new system, taking into account the biometric characteristics of children, age, health parameters (eyes, heart, nerves, etc.) and psychological condition.

\section{Conclusion}

The reality is that the Internet is almost irreplaceable for children to acquire knowledge, learn more without anyone, have fun, communicate, develop their talents and socialize. Prohibitions on children, on the other hand, are less effective in protecting them from harmful information. Therefore, various applications and parental control programs are offered by professionals to meet the interests and needs of children and adolescents, as well as to act as a more reliable source for them. Access to malicious information is prevented by various methods. Harmful information is detected or various filters are applied.

The results of the experiments show that providing children with age-appropriate information is important for their protection in the virtual space. Based on the results, the preferred type of information to be presented to the children's audience is determined. Compared to other alternatives, preference is given to information that is not harmful to the minor user. This information is suitable for children's audiences and has an accuracy of 0.382997. 
The use of this approach by parents, educational institutions, etc. can be helpful in protecting children and adolescents from harmful information obtained from the global network.

\section{References}

[1] Law of the Republic of Azerbaijan "On protection of children from harmful information” October 30, 2018, http://www.eqanun.az/framework/40764

[2] T.H. Kazimov, S.S. Ojagverdiyeva, Analysis of software tools that ensure the safety of children on the Internet// I Republican conference "Actual scientific-practical problems of software engineering", Bak1, 2017, pp. 305-307.

[3] I.Y Alakbarova, S.S.Ojagverdiyeva, Problems of safety of children and adolescents on the Internet and their solution using big data technologies //Telecommunications №4 за 2020, C. 23-31, doi: 10.31044/1684-2588-2020-0-4-23-31

[4] Rasim Alguliyev, Sabira Ojagverdieva,"Conceptual Model of National Intellectucal System for Children Safety in Internet Environment", International Journal of Computer Network and Information Security(IJCNIS), Vol.11, No.3, pp.40-47, 2019.DOI: 10.5815/ijcnis.2019.03.06

[5] R. Tahir, F. Ahmed, H. Saeed, S. Ali, F. Zaffar, and C. Wilson, "Bringing the kid back into youtube kids: Detecting inappropriate content on video streaming platforms," in IEEE/ACM International Conference on Advances in Social Networks Analysis and Mining, 2019.

[6] European Commission, "Protection of personal data," http://ec.europa.eu/justice/data-protection/, November 242016

[7] Smahel, D., Machackova, H., Mascheroni, G., Dedkova, L., Staksrud, E., Ólafsson, K., Livingstone, S., and Hasebrink, U. (2020). EU Kids Online 2020: Survey results from 19 countries. EU Kids Online. https://doi.org/10.21953/lse.47fdeqj01ofo

[8] D. Patel and P. K. Singh, "Kids safe search classification model", 2016 International Conference on Communication and Electronics Systems (ICCES), Coimbatore, 2016, pp. 1-7, DOI: 10.1109/CESYS.2016.7914186.

[9] A.N.A Kamarudin, B. Ranaivo-Malançon and N.Musa, "Design and Implementation of PIAK: A Personalized Internet Access System for Kids", Journal of Telecommunication, Electronic and Computer Engineering, Vol. 9 No. 2-9, pp. 49-57.

[10] Soumen Roy, Utpal Roy, and D. D. Sinha, "Protection of Kids from Internet Threats: A Machine Learning Approach for Classification of Age-group Based on Typing Pattern," Lecture Notes in Engineering and Computer Science: Proceedings of The International MultiConference of Engineers and Computer Scientists 2018, 14-16 March, 2018, Hong Kong, vol. 1, pp. 399-404.

[11] Uzun Y, Bicakci K, Uzunay Y (2015) Could We Distinguish Child Users from Adults Using Keystroke Dynamics? arXiv:1511.05672

[12] J. Zeniarja, R.R.Sani, A. Luthfiarta, H.Agus Susanto, E.Yudi Hidayat, A.Salam, L.Bayu Mahendra, "Search Engine for Kids with Document Filtering and Ranking Using Naive Bayes Classifier," 2018 International Seminar on Application for Technology of Information and Communication, Semarang, 2018, pp. 560-564, doi: 10.1109/ISEMANTIC.2018.8549707.

[13] Abdullayeva, F.J. and Ojagverdiyeva, S.S. (2019) 'Deep learning based data sanitization method for child prodection on the internet', Optical-Electronic Devices and Devices in Systems Image Recognition \& Image Processing, 'Recognition - 2019'/ XV International Scientific And Technical Conference, Kursk, Russia, pp.16-18.

[14] R.M Alguliyev, FJ Abdullayeva, SS Ojagverdiyeva, Protecting children on the internet using deep generative adversarial networks, International Journal of Computational Systems Engineering, vol. 6, №2, pp. 84-90.

[15] A. N. A. Kamarudin and B. Ranaivo-Malançon, "Simple Internet Filtering Access For Kids using Naive Bayes and Blacklisted URLs," in International Knowledge Conference, 2015.

[16] R.Rajalakshmia, HansTiwari, JayPatel, Ankit Kumar and R.Karthik, Design of Kids-specific URL Classifier using Recurrent Convolutional Neural Network, Procedia Computer Science, vol.167, 2020, pp. 2124-2131

[17] M.Charalambous, P.Papagiannis, A.Papasavva, P.Leonidou, R.Constaninou, L. Terzidou, Th.Christophides, P.Nicolaou, O.Theofanis, G.Kalatzantonakis and M.Sirivianos (2020) A Privacy-Preserving Architecture for the Protection of Adolescents in Online Social Networks, arXiv:2007.12038v2 [cs.SI] 18 Sep 2020

[18] K.Papadamou, A.Papasavva, S.Zannettou, J.Blackburn, N.Kourtellis, I.Leontiadis, G.Stringhini \& Sirivianos, M. (2020). Disturbed YouTube for Kids: Characterizing and Detecting Inappropriate Videos Targeting Young Children. Proceedings of the International AAAI Conference on $\mathrm{Web}$ and Social Media, 14(1), 522-533. Retrieved from https://ojs.aaai.org/index.php/ICWSM/article/view/7320

[19] Alghowinem S. (2019) A Safer YouTube Kids: An Extra Layer of Content Filtering Using Automated Multimodal Analysis. In: Arai K., Kapoor S., Bhatia R. (eds) Intelligent Systems and Applications. IntelliSys 2018. Advances in Intelligent Systems and Computing, vol 868. Springer, Cham. https://doi.org/10.1007/978-3-030-01054-6_21

[20] ElTayeby O, Abdullah M, Burlinson D, et al. Detecting drinking-related contents on social media by classifying heterogeneous data types. In: Benferhat S, Tabia K and Ali M (eds). Advances in artificial intelligence: from theory to practice. Cham: Springer, 2017, pp. 364-373.

[21] M. Velasquez and P. T. Hester. 2013. An analysis of multi-criteria decision-making methods. International Journal of Operations Research 10, pp. 56-66.

[22] R. Nagpal, D. Mehrotra, P. Kumar Bhatia, A.Sharma, Rank university websites using fuzzy AHP and fuzzy TOPSIS approach on usability. I.J. Information Engineering and Electronic Business, 2015, 1, pp. 29-36

[23] V. Listyaningsih, E.Utami, "Decision Support System Performance-Based Evaluation of Village Government using AHP and TOPSIS Methods: Secang Sub-district of Magelang Regency as a Case Study", International Journal of Intelligent Systems and Applications(IJISA), 2018, vol.10, No.4, pp.18-28.

[24] T. K. Das, D. P. Acharjya, M. R. Patra,"Multi Criterion Decision Making using Intuitionistic Fuzzy Rough Set on Two Universal Sets", International Journal of Intelligent Systems and Applications(IJISA), vol.7, no.4, pp.26-33, 2015. doi: 10.5815/ijisa.2015.04.04

[25] D. J. Y. Tey, Y. F. Gan, G. Selvachandran, S. G. Quek, F. Smarandache, L. H Son, M. A. Basset, and H. V Long, “A Novel 
Neutrosophic Data Analytic Hierarchy Process for Multi-Criteria Decision-Making Method: A Case Study in Kuala Lumpur Stock Exchange", Special Section on New Trends In Brain Signal Processing and Analysis, IEEE Access, Vol. 7, pp. 5368753697, 2019.

[26] S. Paul, and B. K. Mishra, "Selection of next generation anti-virus against virus attacks in networks using AHP," International Journal of Computer Network and Information Security, vol. 2, pp. 29- 35, 2013.

[27] T. L. Saaty, “How to make a decision: The analytic hierarchy process,'” Eur. J. Oper. Res., vol. 48, pp. 9-26, Sep. 1990.

[28] Yan Liu, Xin Zhang, " Evaluating the Undergraduate Course based on a Fuzzy AHP-FIS Model", International Journal of Modern Education and Computer Science(IJMECS), Vol.12, No.6, pp. 55-66, 2020.DOI: 10.5815/ijmecs.2020.06.05

[29] Adel A. Nasser, Abdualmajed A. Al-Khulaidi, Mijahed N. Aljober, "Measuring the Information Security Maturity of Enterprises under Uncertainty Using Fuzzy AHP", International Journal of Information Technology and Computer Science(IJITCS), Vol.10, No.4, pp.10-25, 2018. DOI: 10.5815/ijitcs.2018.04.02

\section{Authors' Profiles}

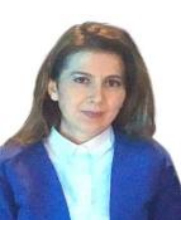

Fargana J. Abdullayeva graduated from the 'Computer Techniques and Technologies' faculty of the Sumgait State University in 2002. In 2003, she was accepted for employment at the Institute of Information Technology of the ANAS, where she addressed issues of information security provision. In 2004, as a respondent, she commenced her work on the subject of 'Development of methods and algorithms for providing information security of population and migration system'. In 2010, defense of the thesis took place. At present, she conducts researches on cloud computing security, anomaly detection, load balancing and task scheduling.

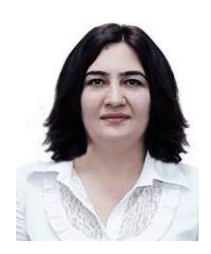

Sabira S. Ojagverdiyeva graduated from Applied Mathematics faculty of Baku State University (BSU). Since the same year, she began working Institute of Information Technology of ANAS. Her area of interest includes information security, on Internet child protection, data sanitization and Data Mining technologies. She carries out scientific research on "Ensuring children's safety on Internet" in the field of information security.

How to cite this paper: Fargana J. Abdullayeva, Sabira S. Ojagverdiyeva, "Multicriteria Decision Making using Analytic Hierarchy Process for Child Protection from Malicious Content on the Internet", International Journal of Computer Network and Information Security(IJCNIS), Vol.13, No.3, pp.52-61, 2021. DOI: 10.5815/ijcnis.2021.03.05 